\title{
(a) BiLGiDIDÜNASI
}

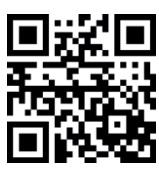

e-ISSN: 2148-354X

Karamanoğlu Mehmetbey Üniversitesi Türk Dili ve Edebiyatı Bölümü ile Bakü Devlet Üniversitesi Azerbaycan Dili ve Edebiyatı Bölümü Öğrencilerinin Okuma Alışkanlıkları Üzerine Karşılaştırmalı Bir İnceleme

Comparative Study on Reading Habits of the Students between Karamanoglu Mehmetbey University Turkish Language and Literature Department and Baku State University Azerbaijan Language and Literature Department

Eda Peri ERBAŞ, Bülent YILMAZ

\section{Makale Bilgisi / Article Information}

Bu makaleye atıf yapmak için/ To cite this article:

Erbaş, E. P. ve Yılmaz, B. (2019). Karamanoğlu Mehmetbey Üniversitesi Türk Dili ve Edebiyatı Bölümü ile Bakü Devlet Üniversitesi Azerbaycan Dili ve Edebiyatı Bölümü öğrencilerinin okuma alışkanlıkları üzerine karşılaştırmalı bir inceleme. Bilgi Dünyast, 20(2), 119-142. doi: 10.15612/BD.2019.725

Makale türü / Paper type: Hakemli / Refereed

\section{Araştırma Makalesi / Research Article}

Doi: $10.15612 / B D .2019 .725$

Geliş Tarihi / Received: 11.12 .2018

Kabul Tarihi / Accepted: 12.09.2019

Elektronik Yayınlanma Tarihi / Online Published: 31.10.2019

\section{Iletişim / Communication}

Üniversite ve Araştırma Kütüphanecileri Derneği / University and Research Librarians Association Posta Adresi / Postal Address: Marmara Sok. No:38/1706420 Yenişehir, Ankara, TÜRKIYE/TURKEY Tel: +90 31243003 61; Faks / Fax: +90 31243003 61; E-posta / E-mail: bilgi@bd.org.tr Web: http://www.bd.org.tr/index.php/bd/index 


\title{
Karamanoğlu Mehmetbey Üniversitesi Türk Dili ve Edebiyatı Bölümü ile Bakü Devlet Üniversitesi Azerbaycan Dili ve Edebiyatı Bölümü Öğrencilerinin Okuma Alışkanlıkları Üzerine Karşılaştırmalı Bir İnceleme*
}

\author{
Eda Peri ERBAŞ** (D), Bülent YILMAZ*** (iD
}

\begin{abstract}
Öz
Hızla gelişen bilgi teknolojisi gençlerin okuma alışkanlıklarını etkilemektedir. Günümüzde gençlerin okuma alışkanlığı üzerine araştırmalaryapmakönemini korumaktadır. Türkçe literatürde okuma alışkanlığı ile ilgili özellikle kültürlerarası çalışmalara çok fazla rastlanmamaktadır. Bu çalısmada farklı coğrafyalarda yer almasına rağmen ortak bir kültüre sahip olan iki ülkede (Türkiye ve Azerbaycan) bulunan Karamanoğlu Mehmetbey Üniversitesi (KMÜ) Türk Dili ve Edebiyatı (TDE) Bölümü ile Bakü Devlet Üniversitesi (BDÜ) Azerbaycan Dili ve Edebiyatı (AZE) Bölümü son sınıf öğrencilerinin okuma alışkanlıkları karşılaştırmalı olarak incelenmiştir. Bu bağlamda araştırmanın temel amacı KMÜ Türk Dili ve Edebiyatı Bölümü ile BDÜ Azerbaycan Dili ve Edebiyatı Bölümü son sınıf öğrencilerinin okuma alışkanlığı konusunda benzer ve farklı özelliklerinin hangi etkenlerden kaynaklandığını ortaya koymaktır. Araştırmada betimleme ve karşılaştırma yöntemi kullanılmıştır. Bu amaçla her iki üniversiteden toplam 187 öğrenciye anket uygulanmıştır. Sonuçlar SPSS 21 istatistik programı üzerinden değerlendirilmiştir. Araştırma kapsamına dâhil edilen iki bölüm öğrencilerine uygulanan anket ile elde edilen veriler arasında çeşitli açılardan yapılan karşılaştırmalarda Ki-Kare analizi uygulanmıştır. Araştırma sonuçlarına göre, öğrenciler ders kapsamı dışında çoğunlukla ayda ortalama bir kitap okumaktadırlar. Her iki bölüm öğrencileri de kitap okumaktan orta düzeyde hoşlanmakta ve okuma alışkanlığı kazandırmanın bir öğretmen için kesinlikle önemli olduğunu düşünmektedirler. Bu bölümlerdeki öğrenciler okuma alışkanlığı kazandırma konusunda gerekli bilgi ve beceriye tamamen sahip olmadıklarını düşünmektedirler. Çalışmanın sonunda ilgili bölüm programlarına okuma alışkanlığı ile ilgili ders/içerik konulması önerilmiştir.
\end{abstract}

Anahtar sözcükler: Okuma alışkanlığı, üniversite öğrencileri, Türk/Azerbaycan Dili ve Edebiyatı Bölümü.

* Bu çalışma 2018 yılında Hacettepe Üniversitesi Sosyal Bilimler Enstitüsü Bilgi ve Belge Yönetimi Anabilim Dalında Prof. Dr. Bülent YILMAZ danışmanlığında "Karamanoğlu Mehmetbey Üniversitesi Türk Dili ve Edebiyatı Bölümü ile Bakü Devlet Üniversitesi Azerbaycan Dili ve Edebiyatı Bölümü Öğrencilerinin Okuma Alışkanlıkları Üzerine Karşılaştırmalı Bir İnceleme" başlıklı tamamlanmış yüksek lisans tezine dayanarak hazırlanmıştır.

** Sorumlu Yazar, Yüksek lisans mezunu, Hacettepe Üniversitesi, Edebiyat Fakültesi, Bilgi ve Belge Yönetimi Bölümü, parvana1985@hotmail.com.

*** Prof. Dr., Hacettepe Üniversitesi, Edebiyat Fakültesi, Bilgi ve Belge Yönetimi Bölümü, byilmaz@hacettepe.edu.tr 


\title{
Comparative Study on Reading Habits of the Students between Karamanoglu Mehmetbey University Turkish Language and Literature Department and Baku State University Azerbaijan Language and Literature Department*
}

\author{
Eda Peri ERBAŞ** (D), Bülent YILMAZ***(i)
}

\begin{abstract}
Rapidly developing information technology affects the reading habits of young people. At the present time, research on reading habits of young people is still important. There is not a lot of intercultural studies on reading habits in Turkish literature. In this study were comparatively examined the similar and different features about reading habits of Karamanoglu Mehmetbey University (KMU) Turkish Language/Literature and Baku State University (BSU) Azerbaijan Language/Literature Departments last year students that despite having common culture taking place in different regions (Turkey and Azerbaijan). In this context, the main aim of the study is to determine the similar and different characteristics of the reading habits the last year students of KMU Turkish Language/Literature Department and BSU Azerbaijan Language/Literature Department. In this research were used description and comparison methods. For this purpose, a total of 187 students from both universities were surveyed. The results were evaluated using SPSS 21 statistical program. The chi-square analysis was applied to the data obtained from the two groups of students included in the study. According to the results of the research, the students are reading a book monthly. The students of the both departments, enjoy reading books at a mid level and they think that it is absolutely important for a teacher to gain reading habits. Students in these departments think that they do not have all the necessary knowledge and skills to gain reading habit. At the end of the study, it is suggested to put the lecture/content related to reading habit into the involved department programs.
\end{abstract}

Keywords: Reading habits, university students, Turkish / Azerbaijan Language and Literature Department.

* This study was prepared according to the thesis "Comparative Study on the Reading Habits of Students between Karamanoglu Mehmetbey University Turkish Language and Literature Department and Baku State University Azerbaijan Language and Literature Department" under the supervision of Prof. Bulent Yılmaz (Ph.D) at Hacettepe University, Institute of Social Sciences, Department of Information Management in 2018.

* Corresponding Author, Master's Degree Graduate, Hacettepe University, Faculty of Literature, Department of Information Management, parvana1985@hotmail.com

*** Prof. (Ph.D), Hacettepe University, Faculty of Literature, Department of Information Management, byilmaz@ hacettepe.edu.tr 


\section{Giriş}

Insanların bilgilenmesini ve gelişimini gerçekleştiren bir eylem olan okuma, görme, dikkat, algılama, hatırlama, seslendirme, anlamlandırma, sentezleme, çözümleme ve yorumlama gibi farklı bileşenlerden oluşan, karmaşık bir zihinsel süreçtir. Okuma, sadece görme ve algılamadan ibaret değil, birçok fiziksel ve zihinsel etkinliğin birlikte gerçekleşmesiyle oluşan bir beceridir (Coşkun, 2002, s.231, 234). Kitap okuma bireylerin duygu ve düşünce yapısını, hayal dünyasını geliştiren, söz dağarcı̆ı̆ını artıran ve bu bağlamda konuşma becerilerini olumlu etkileyen bir eylemdir.

Modern dünyada okumak, yaş veya eğitim durumuna bakılmaksızın bilgi edinme sürecinin başlıca yöntemlerinden biridir. Buna karşın, günümüzde gençlerin internet, sosyal medya vb. çeşitli kaynaklardan bilgi elde etmeyi daha fazla tercih etmelerinin kitap okuma alışkanlıklarını olumsuz etkilediği belirtilmektedir (Lupinogina ve Zaroçinçeva, 2015, s.142). Bir başka deyişle, bilgi edinme davranışlarında teknolojiye bağlı değişiklikler gençlerin okuma alışkanlıklarını etkileyebilmektedir.

Bu araştırmada Karamanoğlu Mehmetbey Üniversitesi (KMÜ) Türk Dili ve Edebiyatı Bölümü ile Bakü Devlet Üniversitesi (BDE) Azerbaycan Dili ve Edebiyatı Bölümü öğrencilerinin kitap okuma alışkanlığı konusundaki bilinç, tutum ve davranışlarının karşılaştırılarak ortaya konması hedeflenmiştir. Özellikle araştırma kapsamına alınan lisans öğrencilerinin çok kısa bir süre sonra öğretmen olarak göreve başlama durumları, öğrencilerine kitap okuma alışkanlığı konusunda model olma rolleri ve bu alışkanlığı kazandırma sorumlulukları onların bu konudaki bilinç, tutum ve yaklaşımlarını belirlemeyi önemli kılmaktadır. Ayrıca ortak kültüre sahip farklı coğrafyalardaki iki ülke üniversitesi öğrencilerinin durumunu ortaya koymanın bu konuda kültürün etkisini görmek açısından da literatüre katkı sağlaması beklenmektedir.

\section{Literatür Değerlendirmesi}

Literatürde öğretmen adaylarının okuma alışkanlıkları üzerine gerçekleştirilmiş çeşitli araştırmalar yer almaktadır.

Edizer (2015), Türkçe öğretmen adaylarının kitap okuma alışkanlığına ilişkin tutumları ile üst bilişsel okuma stratejilerini kullanma algıları arasındaki ilişkiyi belirlemeyi amaçladığı araştırmasında, öğrencilerin kitap okuma alışkanlığı tutumları arttıkça üst bilişsel okuma stratejileri kullanma algılarının da arttığı sonucuna ulaşmıştır.

Yıldız, Ceren ve Sevmez (2015), çalışmalarında Necmettin Erbakan Üniversitesi Ahmet Keleşoğlu Eğitim Fakültesi öğretmen adaylarının okuma alışkanlığı profillerini belirlemeyi amaçlamışlardır. Araştırma sonuçlarına göre, öğretmen adaylarının; çoğunlukla 1-5 kitap okudukları, okumalarına engel olan unsurlar arasında ilk sırada "okuma alışkanlığının olmaması"nı seçtikleri; okuma alışkanlıklarının sınıf düzeyine 
göre belirgin biçimde farklılaşmadığı; okumalarında etkili olan unsurlarda ilk sırada "arkadaş tavsiyesi"; en çok tercih ettikleri türler arasında ilk sırada roman ve hikâyenin yer aldığı anlaşılmıştır.

Okuma ilgisi, alışkanlığı ve tutumları ile ilgili ilköğretim düzeyinde yapılmış lisansüstü tezlerin karşılaştırmalı bir analizini yaparak var olan durumu ortaya koymayı amaçlayan bir başka çalışmada (Karadağ, 2014) Türkiye'de gerçekleştirilen araştırmaların genellikle yüksek lisans düzeyinde yapıldığı ve tarama modelinde gerçekleştirildiği, veri toplama aracı olarak yapılmış tezlerin büyük çoğunluğunda tutum ölçeği, anket ve başarı testi kullanıldığı, örneklem grubu olarak genellikle ilköğretim 4. ve 5. sınıf düzeylerinde çalışmaların gerçekleştirildiği ortaya çıkmıştır.

Yalman, Erdost ve Kutluca (2013) 2011-2012 eğitim-öğretim yılı baharyarıyılında Dicle Üniversitesi Eğitim Fakültesi'nde öğrenim gören 220 öğrenci üzerine gerçekleştirdikleri araştırmada öğrencilerin okuma alışkanlığını ve bu alışkanlığın içeriğini betimlemeye çalışmıştır. Araştırma sonucunda, öğretmen adaylarının yarısından fazlasının kitap okumayı sevdiği, kitapları temin ederken satın aldıkları veya arkadaşlarından ödünç aldıkları ve kitap okuma tercihlerinin macera türünde olduğu belirlenmiştir. Bunun yanında öğrencilerin önemli bir kısmının okumamalarını ders yoğunluğuna dayalı nedenlerle açıkladıkları görülmüştür.

Çanakkale Onsekiz Mart Üniversitesi Eğitim Fakültesi İlköğretim Bölümü 3. sınıf öğretmen adaylarının kitap okuma alışkanlıklarını ortaya koyma amacıyla Arı ve Demir (2013) tarafından gerçekleştirilen çalışmada, ilköğretim öğretmen adaylarının kitap okumaya ilişkin tutumlarının cinsiyet değişkenine göre anlamlı olarak değiştiği, buna karşın, ilköğretim öğretmen adaylarının kitap okumaya ilişkin tutumlarının öğrenim gördükleri anabilim dalı, öğretim türü, aile geliri, yaşanılan yerleşim yeri türü, anne eğitim durumu ve baba eğitim durumu değişkenlerine göre ise anlamlı olarak farklılaşmadığı ortaya çıkmıştır.

Batur ve Berk (2010) yaptıkları araştırmada, Uşak Eğitim Fakültesi'nde öğrenim görmekte olan öğretmen adaylarının kitap okuma alışkanlığına yönelik tutumları ve bu tutumları etkileyen faktörleri belirlemeye çalışmışlardır. Toplam 420 öğrenci üzerinden gerçekleştirilen araştırma sonuçlarına göre, kadın öğrencilerinin erkek öğrencilere göre kitap okuma alışkanlığına yönelik daha olumlu tutuma sahip oldukları görülmüş, genel anlamda ise sınıflara göre, öğrencilerin okuma alışkanlığına karşı tutumlarının olumlu olduğu ortaya çıkmıştır.

Çalışma grubunu Cumhuriyet Üniversitesi Eğitim Fakültesi İlköğretim ve Türkçe Eğitimi Bölümü dördüncü sınıfta öğrenim gören 242 öğretmen adayının oluşturduğu bir başka çalışmada (Bozpolat, 2010) öğretmen adaylarının kitap okuma alışkanlığına yönelik tutumları cinsiyet değişkenine göre incelenmiştir. Araştırmada, cinsiyet değişkenine göre okuma sevgisi boyutunda kız öğrenciler lehine anlamlı bir farklılık 
belirlenmiştir. Alışkanlık, gereklilik, istek, etki ve yarar boyutlarında ise cinsiyet değişkenine göre tutumlarının farklılaşmadığı anlaşılmıştır. Ayrıca bölüm değişkenine bakıldığında bütün boyutlara ilişkin tutumlarda anlamlı bir farklılık gözlenmemiştir.

Mustafa Kemal Üniversitesi Eğitim Fakültesi'ndeki 400 sınıf öğretmeni adayının okuma alışkanlığına yönelik tutumlarının cinsiyete, öğretim türüne ve sınıf düzeyine göre incelenmesini amaçlayan bir başka araştırma (Yılmaz ve Benli, 2010) sonuçlarına göre, sınıf öğretmeni adaylarının okuma alışkanlığına yönelik tutumlarında cinsiyete göre anlamlı bir farklılık olduğu, öğretim türü ve sınıf düzeyine göre anlamlı bir farklılık olmadığı görülmüştür.

Kuş ve Türkyılmaz'ın (2010) çalışmasında Türkçe ve sosyal bilgiler öğretmeni adaylarının okuma alışkanlıkları tespit edilmeye çalışılmıştır. Araştırma sonucuna göre, Türkçe öğretmeni adaylarının okuma sıklıkları sosyal bilgiler öğretmeni adaylarına göre yüksek çıksa da genelde öğretmen adaylarının okuma sıklıkları düşük oranda gerçekleşmiştir. Öte yandan öğrencilerin az okumalarının nedeni olarak, işlerin yoğunluğu ve sınava hazırlanma (\%49) gösterilmiştir.

Türkçe öğretmeni adaylarının okuma alışkanlığına yönelik tutumlarının çeşitli değişkenlere göre farklılık gösterip göstermediklerini belirlemek amacıyla Gazi Üniversitesi Eğitim Fakültesi Türkçe Öğretmenliği Ana Bilim Dalı 1, 2, 3 ve 4. sınıflarında öğrenim gören 320 öğrenci ile gerçekleştirilen bir başka araştırmada (Özbay, Bağcı ve Uyar, 2008) Türkçe öğretmeni adaylarının okuma alışkanlığına yönelik tutumlarında cinsiyet, okuma sıklığı ve süreli yayın izleyip izlememe değişkenlerine göre anlamlı farklılıklar ortaya çıkmıştır.

Sınıf öğretmeni adayları ile sınıf öğretmenlerinin okuma ilgi ve alışkanlıklarının karşılaştırılmasını amaçlayan bir araştırmada (Aslantürk, 2008) Aydın Adnan Menderes Üniversitesi Eğitim Fakültesi ve Aydın il merkezindeki ilköğretim okulları örneklem olarak seçilmiştir. Toplam 151 sınıf öğretmeni adayı ve 203 sınıf öğretmeni araştırma örnekleminde yar almıştır. Araştırma sonuçlarına göre, kadın sınıf öğretmeni adaylarının ve sınıf öğretmenlerinin okuma ilgisi ve okuma alışkanlığı erkek sınıf öğretmeni adaylarının ve sınıf öğretmenlerinin okuma ilgi ve alışkanlığından daha yüksektir. Ayrıca araştırmada, sınıf öğretmeni adayları ve sınıf öğretmenlerinin okuma ilgisinin "orta" düzeyde yer aldığı ve sınıf öğretmeni adaylarının okuma ilgisinin sınıf öğretmenlerinin okuma ilgisinden daha yüksek olduğu anlaşılmıştır

Odabaş, Odabaş ve Polat'ın (2008) yaptıkları araştırmada Ankara Üniversitesi Fen Bilimleri ve Sosyal Bilimlerde öğrenim gören 304 öğrenciye anket uygulanmıştır. Araştırma üniversite öğrencilerinin okuma alışkanlıkları ve becerileri ile kütüphane kullanımı eğilimlerini belirlemenin yanı sıra öğrencilerin cinsiyetlerinin, öğrenim gördükleri alanların ve sınıf farklılıklarının okuma ve kütüphane kullanma alışkanlıklarına etki ettiğini ortaya koymuştur. Özellikle bölümler arasında okuma alışkanlığı açısından 
farklar (sosyal bilimler öğrencileri fen bilimi öğrencilerine oranla daha az kütüphane kullanmaktadırlar) oluşabilmektedir. Sonuç olarak yükseköğrenim boyunca öğrencilerin okuma becerisinde gelişme olduğunu, buna karşın yeterli okuma alışkanlığına sahip olamadıkları görülmüştür.

Gömleksiz (2004) tarafından Fırat Üniversitesi Eğitim Fakültesi öğrencileri üzerinde "geleceğin öğretmenlerinin kitap okumaya ilişkin görüşlerinin değerlendirilmesi" amacıyla yapılan araştırmada, kız öğrencilerin erkek öğrencilere göre kitap okumayı daha fazla sevdiği; okuma alışkanlığı ve okuma isteğinin kız öğrencilerde daha fazla olduğu belirlenmiştir. Hem erkek hem de kız öğrenciler kitap okumanın gerekliliğini kabul ederken, kitap okumanın etkisi ve yararının kız öğrenciler tarafından daha fazla benimsendiği ortaya çıkmıştır.

Gazi Üniversitesi (Ankara)Türk Dilive Edebiyatı Bölümünde öğrenim gören öğretmen adaylarının okuma stratejilerini kullanma düzeyleri incelenmiş olan bu araştırmada öğretmen adaylarının okuma stratejilerini kullanma düzeylerinin cinsiyet değişkenine ilişkin olarak manidar bir farklılık göstermediğini ve öğretmen adaylarının aldıkları akademik eğitimin okuma stratejisi becerilerini destekleyecek ve yetkinleştirecek bir nitelik göstermediğini belirlemiştir (Erdem, 2012, s. 162, 179).

Canik Başarı Üniversitesi (Samsun) Eğitim Fakültesi Türkçe Öğretmenliği ve Psikolojik Danışma ve Rehberlik (PDR) Bölümü birinci sınıf öğrencileri ile Amasya Üniversitesi Türkçe Öğretmenliği Bölümlerinde öğrenim görmekte olan öğretmen adaylarının okuma alışkanlıkları ile doğru yazma becerileri arasındaki ilişkiyi belirlemeye yönelik bu araştırmada, 124 öğrenciye anket uygulanmıştır. Araştırmaya göre öğrencilerin $\% 50,8$ 'nin günde 1-5 saat arası kitap okudukları, \%43,5'nin ise bir saatten daha az okudukları görülmektedir. Araştırmaya katılan öğrencilerin yarısının kitap okumaya günde en az bir saat zaman ayırması olumlu bir sonuçtur. Kitap türü olarak öğrenciler en çok \%84,7 oranla roman-hikâye okuduklarını belirtmişler. Öğrenciler kitap okumaya engel olarak derslerin yoğunluğunu $(\% 38,7)$, kendilerinde okuma alışkanlığının olmamasını (\%29,8), aynı zamanda bilgisayar ve internet kullanım sıklığının fazla olmasını (\%13,7) öne sürmektedirler (Eroğlu, 2013, s. 1441, 1448, 1449).

Azerbaycan, Türkmenistan, Özbekistan, Kazakistan, Kırgızistan gibi bağımsız Türk devletlerinden, Çin sınırları içindeki Doğu Türkistan (Sincan) özerk bölgesinden yükseköğrenim için İstanbul'a gelen Türk asıllı öğrenciler arasında yapılan çalışmaya göre, Azerbaycan'dan gelen öğrencilerin kitap okurken öncelikli olarak tercih ettikleri dil, Azerbaycan Türkçesi ile Türkiye Türkçesidir. İkinci sırada İngilizce ve Rusça gelir. Azerbaycanlı öğrencilerin en çok tercih ettikleri tür ise \%31'lik oranla romandır. En az okunan tür ise felsefî eserlerdir (Hüseynova, 2013, s. 238, 239).

Rajshahi Üniversitesi (Bangladeş) Sosyal Bilimler ve Güzel Sanatlar bölümünde öğrenim gören öğrencilerin okuma alışkanlıklarını değerlendirmek için yapılmış olan 
çalışmada, öğrencilerin büyük bölümü yaşam boyu kendilerini geliştirmek için (\%44) okuduklarını, bazı öğrenciler ise daha iyi iş bulma ve bilgi birikimini artırmak (\%21) için okumayı tercih ettiklerini belirtmiştir. Boş zamanlarını değerlendirmek için (\%3) kitap okumayı tercih edenlerin oranı ise düşüktür. Bu araştırmada bir diğer dikkat çekici nokta ise öğrencilerin okumak için tercih ettikleri kitap türleridir. Verilere göre öğrenciler daha çok ders kitapları (\%42) okumaktadırlar ve diğer kitap türlerini (bilim/kurgu vd.) okuyabilmek için yeterli zamanı bulamadıklarını ifade etmektedirler (Akanda, Eamin, Hoq ve Hasan, 2013).

Rusya'da da, birçok ülkede olduğu gibi, önceki yıllarla kıyaslandığında nüfusun okuma kültüründe bir düşüş meydana geldiği görülmüştür. 1996 yılı ile karşılaştırıldığında kitaplara olan ilgi \%31'den \%22'ye düşerek, \%9 oranında azalmıştır. "Levadaçentr" sosyolojik araştırmalar merkezi tarafından yapılan çalışmaya göre; 1991 yılında Rusya'daki gençlerin \%79'u ayda bir kitap okurken, bu rakam 2008 yılında \%63'e gerilemiştir (Firsova, 2013, s. 103,104).

Bilgi çağında teknolojiye olan eğilim sonucu olarak bireylerin kitap okumaya olan ilgisinin azalma riski olabilir. Oysa okuma alışkanlığının günümüze kadar var olmuş düşünme, dil, iletişim, eğitim ve kişilik geliştirmedeki işlevi bundan sonra da bireysel ve toplumsal yaşamın önemli bir gerçeği olmaya devam edecektir.

\section{Okuma Alışkanlığı ve Öğretmenler}

Teknolojinin hızlı gelişimi gençlerin okuma alışkanlığını etkilemektedir. Gençler daha önceki dönemlerde bilgiye ulaşmak için çoğunlukla kitap, dergi, gazete okumayı, kütüphaneye gitmeyi tercih ederlerken, şimdi internet/sosyal medya ortamından erişmeyi tercih etmektedirler. Gençler böylece kısa metinleri okuyarak bilgiye hızı eriştiklerini ve zaman kazandıklarını düşünmektedirler. Oysa kitap okumak insanların düşüncesini, dil becerilerini, olaylara bakış açısını geliştirmekte, farklı toplumların kültürlerini, tarihini öğrenmeye, dünyayı keşfetmeye yardımcı olmaktadır.

Okuma, insanın zihinsel yetilerini işletmesini, canlı tutmasını hem kendi varlığını hem de başka varlıkları tanımasını, tartmasını, değerlendirmesini ve yeniden üreterek zenginleşmesini sağlayan ve edilgenliğe izin vermeyen bir eylemdir. Okuma eylemi, neredeyse bütün insanlığın çeşitli görüntülerinin edilgen izleyicisi konumuna düşürülmek istendiği bir çağda, geçmişe oranla daha yaşamsal bir önem kazanmıştır (Boz, 2009, s. 26). Okuma alışkanlığı ise, kişinin bir gereksinim olarak algılaması sonucu, okuma eylemini yaşam boyu sürekli, düzenli ve eleştirel bir biçimde gerçekleştirilmesine denir (Yılmaz, 1990, s. 5).

Çeşitli kaynaklarda okuma alışkanlığını belirleyen sıklık dereceleri yer almaktadır. Okur tiplerini belirlemede önemli olan şey belli bir zaman aralığında okuma eylemine ayrılan zaman ile okunan kitapların sayısıdır. Kitap okuma sıklığı Maraşlı'ya göre (2005, 
s. 18) "kişilerin bir yıl boyunca ders dışı okudukları kitap sayısı"dır. Amerikan Kütüphane Derneği (American Library Association-ALA)'nin (1978, s. 3) gerçekleştirdiği bir çalışmada kullanılan, ayrıca Yılmaz (2004, s116)'ın önerdiği sıklıklardan ${ }^{1}$ yararlanılarak oluşturulan ve bu çalışmada esas alınan okuma sıklıkları şöyledir:

Az Okuyan Okuyucu: Yılda 1-5 arası kitap okuyan kişi

Orta Düzeyde Okuyan Okuyucu: Yılda 6-20 adet kitap okuyan kişi;

Çok Okuyan Okuyucu: Yılda 21 ve daha fazla kitap okuyan kişi.**

Okuma sıklık ve düzeyleri ülkelere, toplumlara ve zamana göre değişiklikler gösterebilir.Fakatdeğişmeyendurumokumanın, kişilerinbilgibirikiminizenginleştirmesi, alışkanlık haline dönüşen okuma eyleminin ise bireylerin düzenli olarak bilgi birikimini artırmasına neden olmasıdır. Bu nedenle çocuklara küçük yaşlardan okuma eylemini sevdirmek aynı zamanda bu eylemi bir alışkanlık haline dönüştürmek önemlidir. Okuma alışkanlığı kazandırmada çocukluk ve gençlik en önemli dönemlerdir. Bu dönemlerde çocuklar okuma eylemini alışkanlık haline dönüştürürlerse, o zaman bu alışkanlık yaşam boyu düzenli bir şekilde devam eder ve kalıcı hale gelir. Okullar ise öğrencileri hayata ve üst düzey eğitim/öğrenime hazırlamakla birlikte onların genel kültürünü geliştirmektedir. Okullarda öğretmenler öğrencilere bir model oluşturmaktadırlar.

Okuma alışkanlığının kazandırılmasında çocukluk, gençlik ve yetişkinlik olmak üzere üç dönemden söz edilebilir. Ancak okuma alışkanlığı temelde ilköğretim yıllarında yani çocuklukta kazandırılır. Okul çağında okuma alışkanlığı kazanamamış bireylerin yetişkinlik dönemlerinde bu beceriyi kazanmaları oldukça güçtür. Bu sebeple öğrenciler en geç ilköğretimin ikinci kademesinde okuma alışkanlığı kazanmış olmalıdır. Kişilik oluşumunun başladığı, algılama ve etkilenmenin yoğun olduğu, bedensel ve ruhsal gelişmenin hızlandığı ve yaşama hazırlık diye nitelenen çocukluk döneminde verilecek bir okuma desteği, onun yetişkinlikteki okuma alışkanlığının temelini oluşturacaktır (Serin, 2011, s. 10).

Okuma alışkanlığı kazandırma konusunda öğretmenler, öğrencilerin kendi ilgi ve becerilerini keşfetmeleri için uygun ortam ve koşullar hazırlayabilen, onlara düşünme, üretme, kendini ifade edebilme ve okuma-yazma becerilerini geliştirerek yaratıcı yönlerini keşfetmelerini sağlayan kişiler olarak, ne kadar bilgili, araştıran, sorgulayan ve etkin bir yapıda olurlarsa yetiştirdiği öğrencileri de aynı özelliklerle donatacaklardır (Aslantürk, 2008, s. 5).

Eğitim, yaşam boyu sürdürülmesi gereken bir süreç olduğu için, öğretmenlerin bilgilerini güncel tutmak ve kendilerini sürekli geliştirmek zorunda oldukları açıktır. Öğretmenler zaman bulduklarında değil, bizzat zaman yaratarak okumak ve kütüphane kullanmak durumundadırlar. Başarı için bu son derece önemli bir gerekliliktir (Yılmaz, 2002, s. 445).

1 Bu çalışmada esas alınan okuma sıklıkları yöntem bölümünde belirtilmiştir. 
Eğitimin tüm aşamalarında olduğu gibi okuma alışkanlığı kazandırma konusunda da en önemli etkenlerden biri olan öğretmenler, ebeveynlerden sonra çocukların en çok iletişimde bulunduğu ve örnek aldığı kişilerdir. Bu nedenle öğretmenler öğrencilere okuma alışkanlığı kazandırma konusunda okumayı zevkli hale getirecek eğlenceli ve yaratıcı yollar geliştirerek, okumayı zorla değil, severek ve isteyerek yapılan bir eylem haline dönüştürebilmektedirler. Bu görev sadece ilköğretim öğretmenlerine değil, eğitim/öğretimde yer alan tüm öğretmenlere özellikle Türk/Azerbaycan Dili ve Edebiyatı dalında eğitim veren öğretmenlere düşmektedir.

Öğretmenlerin öğrencilere okuma alışkanlığı kazandırması ve bu alışkanlıklarını geliştirmesi konusundaki rolleri tarafımızdan şu noktalarda toplanmıştır:

1. Öğretmen diğer konularda olduğu gibi okuma alışkanlığı konusunda da öğrenciler için bir rol modeldir. Okuyan, okuma alışkanlığı, bilinci ve duyarlılığı olan öğretmen öğrencileri için "taklit" edilen bir model (örnek) olacaktır. "Okuyan öğrenci için okuyan öğretmen gerekir" yaklaşımı söz konusudur.

2. Özellikle anadil dersi (bu Türkçe/Azerice) öğretmenleri okuma alışkanlığı konusunda diğer alan öğretmenlerine göre öğrencilerine okuma alışkanlığı kazandırma ve geliştirme konusunda fiilen daha fazla sorumluluğa sahiptir. Çünkü okuma, anadilde okuma ile başlar ve bunun eğitim-öğretimini bu alanın öğretmenleri gerçekleştirir.

3. Öğretmenlerin öğrencilerine okuma alışkanlığı kazandırıp geliştirebilmesi için bu konuda yeterli bilgi, bilinç, duyarlılık ve beceriye sahip olmaları gerekmektedir. Türk/ Azerbaycan Dili ve Edebiyatı alan mezunu öğretmenlerin bu konudaki yeterlilikleri bölüm eğitim programlarının içeriklerinden dolayı biraz daha yüksek sayılabilir.

4. Özellikle okuma alışkanlığı konusunda aile bilinç ve duyarlılığı görece yetersiz toplumlarda çocuklara bu alışkanlığı kazandırma rolü ağırlıkla öğretmenlere düşmektedir. Onlar bir anlamda ebeveynlerin de rollerini üstlenmektedirler. Dolayısıyla öğretmenlerin bu rolü gerçekleştirme yeterliliğine sahip olmaları, bir ülke için son derece önemli görünmektedir.

5. Öğretmenler özellikle lisans eğitimleri boyunca öğrencilere okuma alışkanlığı kazandırma ve geliştirme konusunda eğitim almakta, bu konuda bilgi ve beceri kazanmaktadır. Dolayısıyla öğretmenler çocuklara okuma alışkanlığı kazandırma konusunda meslekleri gereği bilgi, beceri, sorumluluk ve role sahip bir gruptur.

6. Öğretmenler öğrenciler ile eğitim-öğretim temelli bir sürecin içinde çok yoğun ve sistematik biçimde birlikte olmaktadırlar. Öğretmenler genel olarak öğrencilerin kişilik kazanmalarında, yaşam biçimi geliştirmelerinde, alışkanlık edinmeleri ve pekiştirmelerinde belirleyici rol oynarlar. Bu nedenle öğretmenlerin bir yaşam biçimi parçası olarak çocuklara okuma alışkanlığı kazandırma ve geliştirme olanakları oldukça geniştir. 
Kısaca, öğretmenler çocuklara okuma alışkanlığı kazandırma ve geliştirmede çok önemli roller üstlenen başlıca meslek gruplarından birisi olarak kabul edilebilir.

\section{Türkiye ve Azerbaycan'da Öğretmen Yetiştirme Sistemi}

Öğretmenlik meslek olarak sorumluluk gerektiren bir meslektir. YÖK (Yüksek Öğretim Kurulu) kurulduktan sonra Türkiye Cumhuriyeti'nde öğretmen yetiştirme konusundaki değerlendirmeler 17 Nisan 2005 tarihinde resmî gazetede yayımlanan 29329 sayılı MEB'in

'Öğretmen Atama ve Yer Değiştirme Yönetmeliğine göre gerçekleştirilmektedir (2005). MEB'in 29329 sayılı yönetmeliğine göre öğretmen adayları KPSS (Kamu Personeli Seçme Sınavı) ve ÖABT (Öğretmenlik Alan Bilgisi Testi)'den aldıkları puanla atanmaktadırlar. Bir yıl boyunca aday öğretmen olarak görev yaptıktan sonra Bakanlıkça gerçekleştirilen yazılı veya yazılı/sözlü sınav sürecini başarıyla tamamlayanlar öğretmen olarak görevlerini sürdürebilmektedir.

Ayrıca KPSS sınavından gereken şartları sağlayamayan ve taban puanları 50 olan öğretmen adayları okullarda sözleşmeli olarak çalışabilirler. Dört yıl sonra sözleşmeli öğretmenlik görevlerini başarıyla bitirenler talep ettikleri takdirde görev yaptıkları okula kadrolu öğretmen olarak atanabilirler (Kolcu, 2016).

Karamanoğlu Mehmetbey Üniversitesi Türk Dili ve Edebiyatı Bölümünün eğitim süresi dört yıldır. Sınav sistemi 100'lük not üzerinden değerlendirilmektedir. Mezun olabilmek için 240 AKTS'yi sağlamak, genel not ortalaması 4'lük sistemde en az 2 olmak ve müfredat gerekliliklerini sağlamak gerekmektedir (KMÜ, 2017).

Azerbaycan Cumhuriyeti Bakanlar Kurulunun "Yükseköğretim kurumlarında lisans ve yüksek lisans derecesinde eğitim sisteminin düzenlenmesine" ilişkin kuralların onaylanması hakkında 348 sayılı Kararname [348 Nömrəli Qərar]'ye göre (2013) lisans derecesini bitirmek için toplam 240 kredi toplamak gerekmektedir. Sınav sistemi 100'lük not üzerinden değerlendirilmektedir.

Özetle, Azerbaycan Dili ve Edebiyatı Bölümü mezunları MEB ve Devlet Sınav Merkezinin (DSV) düzenlediği sınavlardan yeterli puan almaları durumunda Millî Eğitim Bakanlığı tarafından öğretmen olarak atanabilir veya yükseköğretim kurumlarında araştırmacı olarak çalışabilirler. Azerbaycan'da öğretmen yetiştirme sistemi Azerbaycan Cumhuriyeti Anayasası [Azərbaycan Respublikası Konstitusiyası] (1995), A. C. 324 sayılı Eğitim Kanunu [324 Nömrəli Azərbaycan Respublikası Təhsil Haqqında Qanunu] (1992), Azerbaycan Cumhuriyeti Bakanlar Kurulunun "Yükseköğretim kurumlarında lisans ve yüksek lisans derecesinde eğitim sisteminin düzenlenmesine" ilişkin kuralların onaylanması hakkında 348 sayılı Kararname (2013) ve aynı zamanda eğitim alanındaki diğer hukuki nitelik taşıyan belgelerle gerçekleştirilmektedir. 


\section{Araştırmanın Amacı, Kapsam ve Yöntemi}

Bilgili, özgür ve yaratıcı düşünme yeteneğine sahip olmak için öğrencilerin kitap okuma alışkanlığı kazanmaları önemlidir. Bu durumda çocukluk ve gençlik dönemi okuma alışkanlığının kazandırılmasında önemli zaman dilimidir.

Bu bağlamda araştırmanın temel amacı; farklı coğrafyalarda yer alan ve ortak bir kültüre sahip iki ülkede (Türkiye ve Azerbaycan) bulunan KMÜ Türk Dili ve Edebiyatı Bölümü ile BDÜ Azerbaycan Dili ve Edebiyatı Bölümü son sınıf öğrencilerinin okuma alışkanlığı konusunda benzer ve farklı özelliklerini ortaya koymaktır. Araştırmanın problemi; "KMÜ Türk Dili ve Edebiyatı Bölümü ile BDÜ Azerbaycan Dili ve Edebiyatı Bölümü son sınıf öğrencilerinin okuma alışkanlığı konusunda benzerlik ve farklılıkları nelerdir?" şeklinde ifade edilmiştir. Bu doğrultuda araştırmanın hipotezi; "Farklı coğrafyalarda olmasına karşın ortak bir kültüre sahip oldukları için, KMÜ Türk Dili ve Edebiyatı Bölümü ile BDÜ Azerbaycan Dili ve Edebiyatı Bölümü son sınıf öğrencilerinin okuma alışkanlıkları açısından benzer özellikleri farklı özelliklerine göre daha fazladır." biçiminde belirlenmiştir.

Söz konusu iki üniversite, eğitim sistemlerinde farklılıklar olmasına karşın, ortak kültüre ve benzerlik oranı yüksek dillere sahip oldukları için araştırmaya dâhil edilmiştir. Türk Dili ve Edebiyatı ile Azerbaycan Dili ve Edebiyatı Bölümlerinin seçilmesinde en önemli gerekçe, çocuklara okuma alışkanlığı kazandırmada en önemli role sahip kişilerin öğretmenler olması ve bu bölümlerin ağırlıkla öğretmen yetiştiren bölümler niteliği taşımasıdır. Ayrıca bu çalışmanın araştırmacılarından birisinin ilk, orta ve yüksek eğitimini Azerbaycan'da tamamlamış ve halen Türkiye'de yükseköğretime (araştırmaya dâhil edilen Bölümde KMÜ; TDE Bölümü) devam ediyor oluşunun konuya/kurumlara hâkimiyet açısından avantajlar getireceği yaklaşımı da çalışmanın kapsamını belirlemede etkili olmuştur.

Her iki bölümde (TDE; ADE) öğrenim gören öğrencilerin kitap okuma konusunda düşünce ve davranışlarının belirlenmesi amacıyla yapılmış olan bu araştırmada betimleme ve karşılaştırma yöntemi kullanılmıştır. Betimleme genel olarak olay, varlık ve grupların'ne' olduğunu betimler ve açıklar. Bu yolla mevcut durumlar, koşul ve özellikler aynı şekilde ortaya konmaya çalışılır (Kaptan, 1995, s. 59). Karşılaştırma yöntemi ise genel olarak olayların çeşitli yerlerdeki durumunu karşılaştırarak inceler (Baloğlu, 2009, s. 67). Bir başka deyişle, karşılaştırma yöntemi, olgular arasındaki benzerlik ve farklılıkları saptayarak, bu benzerliklerdeki farklılıklar ile farklılıklardaki benzerliklerin neler olduğunu ortaya koymaktadır (Çakın, 1989, s. 7, 15).

ALA (1978, s. 3) ve Yılmaz'ın (2004, s. 116) önerdiği sıklıklardan yararlanılarak oluşturulan ve bu çalışmada esas alınan okuma sıklıkları şöyledir:

Okuyucu olmayan: Hiç kitap okumayan;

Zayıf Okuyucu: 2 ayda 1 kitap ve daha az kitap okuyan; 
Orta Düzey Okuyucu: Ayda ortalama 1 kitap okuyan;

Güçlü Okuyucu: Ayda ortalama 2 kitap ve daha fazla okuyan.

\section{Araştırmanın Evren ve Örneklemi}

Araştırmanın evreni KMÜ TDE Bölümü ile BDÜ ADE Bölümü son sınıf öğrencileridir.

Araştırmaya ait evren, örneklem ve ön-test sayılarını/oranlarını gösteren Tablo 1 aşağıdadır.

Tablo 1. Evren, Örneklem ve Ön Test

\begin{tabular}{lccccc}
\hline \multirow{2}{*}{ Üniversiteler } & Evren & \multicolumn{2}{c}{ Örneklem } & \multicolumn{2}{c}{ Ön Test } \\
\cline { 2 - 6 } & Sayı & Sayı & $\%$ & Sayı & $\%$ \\
\hline KMÜ TDE Bölümü & 117 & 89 & 76,0 & 15 & 12,0 \\
BDÜ ADE Bölümü & 125 & 98 & 78,4 & 15 & 13,0 \\
\hline
\end{tabular}

Çıngı'ya göre (1990, s, 261), 0,99 güven düzeyi ve 0,04 hoşgörü miktarı ile 500 kişiye kadar olan bir evren 101 kişi ile örneklenebilir. Bu çalışmada 242 kişilik evren 187 kişi ile örneklenmiştir. Örneklemin evreni temsil oranı \%77,3'tür. Tablo 1'de sunulan bu sayı ve oranlara göre örneklem evreni temsil etmektedir. Araştırma için gerçekleştirilen öntest, araştırma öncesi belirlenmiş gruplar arasında başlangıç düzeylerini belirlemek ve anketin yapısı hakkında deneklerden geri bildirim almak amacıyla uygulanan testtir. Ön testin sayısının araştırmacının amacı ve hassasiyeti çerçevesinde genellikle 5-10, 50-100 arası olduğu görülmektedir (Altunışık, 2008, s. 10). Ayrıca, ön-test anket yapısı/ sorular hakkında geri bildirimler almak için de uygulanmış, anket buna dayalı olarak gözden geçirilmiştir. Veri toplama tekniği olarak anket uygulanmıştır. Anket soruları bu çalışmanın yazarları tarafından hazırlanmıştır. Herhangi bir hazır ölçek kullanıımamıştır. Basılı formatta hazırlanan anket 52 sorudan oluşmaktadır. Bu çalışmaya yönelik anket uygulaması 21 Eylül 2017 tarihinde BDÜ'de, 12 Ekim 2017 tarihinde ise KMÜ'de gerçekleştirilmiştir. Araştırmaya KMÜ TDE Bölümü son sınıf öğrencilerinden 89 kişi, BDÜ ADE Bölümü son sınıf öğrencilerinden 98 kişi olmak üzere toplam 187 öğrenci katılmıştır. Sonuçlar SPSS 21 istatistik programı üzerinden değerlendirilmiştir. Anketin geçerlilik ve güvenilirliği ön-test (ön-uygulama) ile gerçekleştirilmiştir.

Araştırma kapsamına dâhil edilen iki bölüme ilişkin olarak "öğrencilerin kitap okuma sıklıkları; öğrencilerin kitap okuma nedenleri; öğrencilerin kitap okumaktan hoşlanma durumları; öğrencilerin dergi ve gazete okuma sıklıkları; öğrencilerin kitap okumasına engel olan unsurlar; öğrencilere göre şu anki okuma alışkanlığı durumları; öğrencilere göre öğretmenlerin okuma alışkanlığı kazandırma görevleri; öğrencilerin okuma alışkanlığı kazandırma konusundaki bilgi ve becerilerine yönelik düşünceleri ve öğrencilerin bölümün ders programında okuma alışkanlığı ile ilgili yeterli sayıda ve içerikte dersin olduğuna dair düşünceleri" konularında elde edilen veriler için Ki-kare analizi uygulanmıştır. 


\section{Bulgular ve Değerlendirme}

Ankete BDÜ'den katılan 98 öğrencinin 91'i kadın (\%92,9); 7'si erkek $(\% 7,1)$ KMÜ'den ise ankete katılan 89 öğrenciden 68'i kadın $(\% 76,4)$ ve 21 'i erkek $(\% 23,6)$ 'tir. Her iki üniversitenin verilerine bakıldığında ankete katılım daha çok kadın ağırlıklıdır.

\section{Öğrencilerin Okuma Alışkanlıklarına İlişkin Özellikleri}

Kitap okuma alışkanlığına sahip olma öğrencilerin eğitimsel ve kişisel gelişimi için önemli faktörlerden biridir. Bu nedenle okuma alışkanlığı elde etmek için ders kitaplarından ziyade ders dışı kitap okuma alışkanlığına sahip olmak gerekmektedir.

Öğrencilerin ders kapsamı dışında kitap okuma sıklıklarına yönelik veriler Tablo 2'de sunulmuştur.

Tablo 2. Öğrencilerin Kitap Okuma Sıklıkları

\begin{tabular}{lcccccc}
\hline & \multicolumn{2}{c}{ KMÜ } & \multicolumn{3}{c}{ BDÜ } & P \\
\hline Ders kapsamı dışında ne kadar kitap okursunuz? & Sayı & $\%$ & Sayı & $\%$ & \\
\hline Hiç okumam & 4 & 4,5 & 5 & 5,1 & \\
Iki ayda bir kitap veya daha az (zayıf) & 27 & 30,3 & 18 & 18,4 & \\
Ayda ortalama bir kitap (orta) & 35 & 39,4 & 45 & 45,9 & 0,58 \\
Ayda iki kitap ve daha fazla (güçlü) & 23 & 25,8 & 30 & 30,6 & \\
\hline Toplam & $\mathbf{8 9}$ & $\mathbf{1 0 0 , 0}$ & $\mathbf{9 8}$ & $\mathbf{1 0 0 , 0}$ \\
\hline
\end{tabular}

Tablo 2 verilerine göre, her iki bölümün öğrencileri de ders kapsamı dışında ayda ortalama bir kitap (TDE \%39,4; ADE \%45,9) okumaktadırlar. Her iki bölüm öğrencileri arasında hiç kitap okumayan (TDE \%4,5; ADE \%5,1) öğrencilerin oranı az da olsa mevcuttur. Güçlü okuma sıklığında (ayda 2 kitap ve daha fazla) ADE Bölümü öğrencilerinin oranı $(\% 30,6)$ TDE Bölümü öğrencilerine $(\% 25,8)$ göre fazladır. ADE Bölümü öğrencilerinin okuma alışkanlığı durumları daha olumludur. Araştırma sonucuna göre her iki bölüm öğrencilerinin ders dışı kitap okumaları "orta" olarak değerlendirilebilir. Yapılan Ki-kare analizine göre $(P=0,58)$ iki bölüm öğrencilerinin kitap okuma sıklıkları arasında istatistiksel olarak anlamlı bir farklılık bulunmamıştır.

Öğrencilerin kitap okuma nedenleri araştırmada sorulan sorulardan bir diğeridir. Bu soruyla ilgili veriler Tablo 3'te sunulmuştur. 
Tablo 3. Öğrencilerin Kitap Okuma Nedenleri

\begin{tabular}{lccccc}
\hline & \multicolumn{2}{c}{ KMÜ } & \multicolumn{2}{c}{ BDÜ } & P \\
\hline Neden kitap okursunuz? & Sayı & $\%$ & Sayı & $\%$ & \\
\hline Kendimi geliştirmek için & 39 & 43,8 & 70 & 71,4 & \\
Bilgi birikimimi artırmak için & 22 & 24,7 & 8 & 8,2 & 0,00 \\
Eğitimime katkı sağlamak için & 15 & 16,9 & 6 & 6,1 & \\
Boş zamanımı değerlendirmek için & 13 & 14,6 & 14 & 14,3 & \\
\hline Toplam & $\mathbf{8 9}$ & $\mathbf{1 0 0 , 0}$ & $\mathbf{9 8}$ & $\mathbf{1 0 0 , 0}$ \\
\hline
\end{tabular}

Elde edilen bulgulara göre, her iki bölümün öğrencileri de en çok kendilerini geliştirmek (TDE \%43,8; ADE \%71,4) için kitap okumaktadırlar. Ancak, BDÜ ADE Bölümü öğrencileri için bu nedenin oranı KMÜ TDE Bölümü öğrencilerinin iki katına yaklaşmıştır. Eğitimlerine katkı sağlamak (TDE \%16,9; ADE \%6,1) ve bilgi birikimini artırmak için okuyanların (TDE \%24,7; $A D E \% 8,2$ ) oranı $A D E$ bölümünde TDE Bölümüne göre daha düşüktür. Boş zamanın değerlendirilmesi için okuyanların oranı (TDE \%14,6; ADE \%14,3) ise her iki bölümde de düşüktür. Yapılan Ki-kare analizine göre $(P=0,00)$ iki bölüm öğrencilerinin kitap okuma nedenleri arasında yer alan "kendini geliştirmek" açısından BDÜ, "bilgi birikimini artırma" ve "Eğitime katkı" açılarından da KMÜ öğrencileri lehine istatistiksel olarak anlamlı bir farklılık bulunmuştur.

Öğrencilerin kitap okumaktan hoşlanıp hoşlanmaması durumu önemli görülmüştür. Elde edilen veriler Tablo 4'te yer almaktadır.

Tablo 4. Öğrencilerin Kitap Okumaktan Hoşlanma Durumları

\begin{tabular}{|c|c|c|c|c|c|}
\hline \multirow[b]{2}{*}{ Kitap okumaktan ne kadar hoşlanırsınız? } & \multicolumn{2}{|c|}{ KMÜ } & \multicolumn{2}{|c|}{ BDÜ } & \multirow[t]{2}{*}{$\mathbf{P}$} \\
\hline & Sayı & $\%$ & Sayı & $\%$ & \\
\hline Çok & 40 & 44,9 & 45 & 45,7 & \\
\hline Orta & 46 & 51,8 & 50 & 51,0 & \\
\hline$A z$ & 2 & 2,2 & 2 & 2,2 & 0,47 \\
\hline Hiç hoşlanmıyorum & 1 & 1,1 & 1 & 1,1 & \\
\hline Toplam & 89 & 100,0 & 98 & 100,0 & \\
\hline
\end{tabular}

Araştırma sonuçlarına göre TDE $(\% 51,8)$ ve $\operatorname{ADE}(\% 51,0)$ Bölümü öğrencileri kitap okumaktan ağırlıkla "orta düzeyde" hoşlanmaktadırlar. Her iki bölümde okumayı "çok seven" öğrencilerin oranı (TDE \%44,9; ADE \%45,7) orta olarak değerlendirilmektedir. Araştırmada okumaktan "az hoşlanan" (TDE \%2,2; ADE \%2,2) veya "hiç hoşlanmayan" (TDE \%1,1; ADE \%1,1) öğrencilerin de olduğu anlaşılmıştır. Yapılan Ki-kare analizine göre $(P=0,47)$ iki bölüm öğrencileri arasında kitap okumaktan hoşlanma durumları açısından istatistiksel olarak anlamlı bir farklııık bulunmamıştır. 
Dergi ve gazete okuma sıklığını ölçmek için öğretmen adaylarının hangi sıklıkta dergi ve gazete okuduklarının belirtilmeleri istenmiştir. Bununla ilgili veriler Tablo 5 'te görülmektedir.

Tablo 5. Öğrencilerin Dergi ve Gazete Okuma Sıklıkları

\begin{tabular}{|c|c|c|c|c|c|}
\hline \multirow[b]{2}{*}{ Hangi sıklıkta dergi ve gazete okursunuz? } & \multicolumn{2}{|c|}{ KMÜ } & \multicolumn{2}{|c|}{ BDÜ } & \multirow[t]{2}{*}{$\mathbf{P}$} \\
\hline & Sayı & $\%$ & Sayı & $\%$ & \\
\hline Her gün 3 ve daha fazla gazete, 1 ayda 3 ve daha fazla dergi & 1 & 1,1 & 6 & 6,1 & \\
\hline Her gün 1-2 gazete, bir ayda 1-2 dergi & 11 & 12,4 & 10 & 10,2 & \\
\hline İki/üç günde 1 gazete, iki ayda 1 dergi & 34 & 38,2 & 21 & 21,4 & 0,02 \\
\hline Hiç okumam & 38 & 42,7 & 61 & 62,2 & \\
\hline Diğer & 5 & 5,6 & 0 & 0,0 & \\
\hline Toplam & 89 & 100,0 & 98 & 100,0 & \\
\hline
\end{tabular}

Elde edilen bulgulara göre, hem TDE $(\% 42,7)$ hem de ADE $(\% 62,2)$ Bölümü öğrencileri genellikle hiç dergi ve gazete okumamaktadırlar. Her gün 3 ve daha fazla gazete, 1 ayda 3 ve daha fazla dergi okuyan öğretmen adaylarının (TDE \%1,1; ADE \%6,1) oranı bu iki bölümde oldukça azdır. Bulgulara göre, her iki bölüm öğrencilerinin de dergi ve gazete okuma alışkanlıklarının oldukça "zayıf" olduğu anlaşılmaktadır. Yapılan Ki-kare analizine göre $(P=0,02)$ iki bölüm öğrencileri arasında dergi-gazete okuma sıklıkları açsından BDÜ öğrencileri lehine istatistiksel olarak anlamlı bir farklılık bulunmuştur.

\section{Öğrencilerin Kendi Okuma Alışkanlıklarına İlişkin Düşünceleri}

Öğrencilerden kitap okumalarına engel olan temel unsurları belirtmeleri istenmiştir. İlgili veriler Tablo 6'da sunulmuştur.

Tablo 6. Öğrencilerin Kitap Okumasına Engel Olan Unsurlar

\begin{tabular}{lccccccccccc}
\hline & \multicolumn{3}{c}{ KMÜ } & \multicolumn{7}{c}{ BDÜ } \\
\hline & \multicolumn{2}{c}{ Evet } & \multicolumn{1}{c}{ Hayır } & \multicolumn{1}{c}{ Evet } & \multicolumn{3}{c}{ Hayır } \\
\hline $\begin{array}{l}\text { Varsa kitap okumanıza engel } \\
\text { olan unsurlar nelerdir? }\end{array}$ & Sayı & $\%$ & Sayı & $\%$ & Sayı & $\%$ & Sayı & $\%$ \\
\hline Bilgisayar/internet kullanımı & 42 & 47,2 & 47 & 52,8 & 26 & 26,5 & 72 & 73,5 & 0,03 \\
Derslerin yoğunluğu & 72 & 80,9 & 17 & 19,1 & 71 & 72,4 & 27 & 27,6 & 0,17 \\
Arkadaşlarımla zaman geçirme & 16 & 18,0 & 73 & 82,0 & 6 & 6,1 & 92 & 93,9 & 0,12 \\
Televizyon izleme & 5 & 5,6 & 84 & 94,4 & 3 & 3,1 & 95 & 96,9 & 0,38 \\
Kitap fiyatlarının pahalıı̆ı & 17 & 19,1 & 72 & 80,9 & 42 & 42,9 & 56 & 57,1 & 0,00 \\
Kaldığım ev/yurt koşulları & 18 & 20,2 & 71 & 79,8 & 8 & 8,2 & 90 & 91,8 & 0,17 \\
Diğer & 4 & 4,5 & 85 & 95,5 & 1 & 1,0 & 97 & 99,0 & \\
\hline
\end{tabular}


Araştırmaya katılan her iki bölüm öğrencileri genellikle derslerin yoğunluğundan (TDE \%80,9; ADE \%72,4) dolayı yeteri kadar kitap okuyamadığını belirtmiştir. TDE Bölümü öğrencilerinin okumaya engel olan nedenlerinden biri de bilgisayar/internet kullanımıyken, ADE Bölümü öğrencileri ise kitap fiyatlarının pahalılığını önemli bir neden olarak dile getirmiştir. Bulgulara göre, ağır ders programı, teknolojik gelişim ve kitap fiyatlarının pahalılığı okumayı engelleyen başlıca unsurlar olarak görülmektedir. Yapılan Ki-kare analiziyle elde edilen Tablo 6'daki unsurlara ilişkin P değerleri sırasıyla şöyledir: Bilgisayar-internet kullanımı: 0,03; Derslerin yoğunluğu: 0,17; Arkadaşlarla zaman geçirme: 0,12; TV izleme: 0,38; Kitap fiyatları=0,00; Kaldığı ev: 0,17. Buna göre iki bölüm öğrencilerinin okumama nedenleri arasında yer alan "bilgisayar-internet kullanma" ve "kitap fiyatları" açılarından istatistiksel olarak anlamlı bir fark varken, diğer unsurlar itibariyle anlamlı bir fark bulunmamıştır.

Bir diğer önemli konu ise öğrencilerin şu anda sahip oldukları okuma alışkanlığı düzeyine ilişkin düşünceleridir. Tablo 7'de bu konuyla ilgili veriler sunulmuştur.

Tablo 7. Öğrencilere Göre Şu Anki Okuma Alışkanlığı Durumları

\begin{tabular}{lccccc}
\hline & \multicolumn{3}{c}{ KMÜ } & \multicolumn{3}{c}{ BDÜ } & P \\
\hline Şu an hangi düzeyde bir okuma alışkanlığına sahipsiniz? & Sayı & $\%$ & Sayı & $\%$ \\
\hline Okuma alışkanlığına sahip olduğumu düşünmüyorum. & 1 & 1,1 & 1 & 1,1 \\
Zayıf bir okuma alışkanlığına sahip olduğumu düşünüyorum. & 20 & 22,5 & 15 & 15,3 \\
Orta düzeyde bir okuma alışkanlığına sahip olduğumu & 50 & 56,2 & 55 & 56,0 & 0,50 \\
düşünüyorum. & 18 & 20,2 & 27 & 27,6 \\
Güçlü bir okuma alışkanlığına sahip olduğumu düşünüyorum. & $\mathbf{8 9}$ & $\mathbf{1 0 0 , 0}$ & $\mathbf{9 8}$ & $\mathbf{1 0 0 , 0}$ \\
\hline Toplam & & & &
\end{tabular}

Her iki bölümün öğrencileri de şu anki okuma alışkanlığı düzeylerini genellikle orta (TDE \%56,2; ADE \%56,0) olarak değerlendirmektedir. Güçlü okuma alışkanlığına (TDE \%20,2; ADE \%27,6) sahip olduğunu düşünen öğrencilerin oranı her iki bölümde de çok yüksek değildir. Okuma alışkanlığına sahip olmadığını düşünen öğrenciler ise yok denecek kadar azdır. Elde edilen verilere göre, her iki bölüm öğrencileri orta düzeyde okuma alışkanlığına sahip oldukları söylenebilir. Yapılan Ki-kare analizine göre $(P=0,50)$ iki bölüm öğrencileri arasında halen sahip oldukları okuma alışkanlığı düzeylerine ilişkin kendi düşünceleri açsından istatistiksel olarak anlamlı bir farklılık bulunmamıştır.

\section{Öğrencilerin Okuma Alışkanlığının KazanıIması Süreci İle İlgili Düşünceleri}

Öğrencilere okuma alışkanlığı kazandırmada öğretmenin önemi konusunda sorulan soruyla verdikleri yanıtlardan elde edilen veriler Tablo 8'de görülmektedir. 
Tablo 8. Öğrencilere Göre Öğretmenlerin Okuma Alışkanlığı Kazandırma Görevleri

\begin{tabular}{|c|c|c|c|c|c|}
\hline \multirow[b]{2}{*}{$\begin{array}{l}\text { Okuma alışkanlığı kazandırmak öğretmenlerin asli görevi } \\
\text { midir? }\end{array}$} & \multicolumn{2}{|c|}{ KMÜ } & \multicolumn{2}{|c|}{ BDÜ } & \multirow[t]{2}{*}{$\mathbf{P}$} \\
\hline & Sayı & $\%$ & Sayı & $\%$ & \\
\hline Evet, kesinlikle & 67 & 75,2 & 66 & 67,4 & \\
\hline Kısmen & 7 & 7,9 & 12 & 12,2 & 0,69 \\
\hline Görevidir, ama zorunlu değildir & 15 & 16,9 & 20 & 20,4 & \\
\hline
\end{tabular}

"Öğrencilere okuma alışkanlığı kazandırma bir öğretmenin asli görevi midir?" sorusuna öğretmen adayları en fazla "kesinlikle" (TDE \%75,2; ADE \%67,4), en az ise "kısmen" (TDE \%7,9; ADE \%12,2) yanıtını vermişlerdir. Ancak okuma alışkanlığı kazandırma bir öğretmenin zorunlu olmayan görevi olduğunu (TDE \%16,9; ADE \%20 ,4) düşünenlerin oranının orta düzeyde oluşu önemli bir olumsuzluğu göstermektedir. Yapılan Ki-kare analizine göre $(P=0,69)$ iki bölüm öğrencileri arasında öğretmenlerin okuma alışkanlığındaki rollerine ilişkin düşünceleri açsından istatistiksel olarak anlamlı bir farklılık bulunmamıştır.

\section{Bölümlerin Öğrencilerin Okuma Alışkanlığı Kazandırma Becerilerine Etkisi}

Öğretmen adaylarının mesleklerini icra etmeye başladıklarında öğrencilerine okuma alışkanlığı kazandırma bilgi ve becerisine ne kadar sahip oldukları konusundaki soruya verdikleri yanıtlardan oluşan veriler Tablo 9'da sunulmuştur.

Tablo 9. Öğrencilerin Okuma Alışkanlığı Kazandırma Konusundaki Bilgi ve Becerilerine Yönelik Düşünceleri

\begin{tabular}{lccccc}
\hline & \multicolumn{2}{c}{ KMÜ } & \multicolumn{2}{c}{ BDÜ } & P \\
\hline $\begin{array}{l}\text { Okuma alışkanlığı kazandırma konusunda yeterli bilgi ve } \\
\text { beceriye sahip misiniz? }\end{array}$ & Sayı & $\%$ & Sayı & $\%$ \\
\hline Bu bilgi/beceriye tamamen sahibim & 23 & 25,8 & 29 & 29,6 & \\
Bu bilgi/beceriye kısmen sahibim & 62 & 69,7 & 65 & 66,3 & 0,44 \\
Bu bilgi/beceriye sahip değilim & 4 & 4,5 & 3 & 3,1 \\
Diğer & 0 & 0,0 & 1 & 1,0 \\
\hline Toplam & $\mathbf{8 9}$ & $\mathbf{1 0 0 , 0}$ & $\mathbf{9 8}$ & $\mathbf{1 0 0 , 0}$ \\
\hline
\end{tabular}

Bulgulara göre, öğrencilerin büyük bölümünün, okuma alışkanlığı kazandırma konusundaki bilgi ve beceriye kısmen (TDE \%69,7; ADE \%66,3) sahip olduklarını düşündükleri görülmektedir. TDE Bölümü öğrencilerinin $\% 25,8$ 'i ve ADE Bölümü öğrencilerinin \%29,6'sı okuma alışkanlığı kazandırma konusunda yeterli bilgi ve beceriye sahip olduklarını düşünürken, okuma alışkanlığı konusunda herhangi bir bilgi ve becerisi olmadığını söyleyen öğrencilerin oranının (TDE \%4,5; ADE \%3,1) 
düşük olduğu görülmektedir. Sonuçlara göre, öğrenciler okuma alışkanlığı kazandırma konusunda orta düzeyde bir bilgi ve beceriye sahip olduklarını düşünmektedirler. Bu durum olumsuz bir tabloyu ifade etmektedir. Yapılan Ki-kare analizine göre $(P=0,44)$ iki bölüm öğrencileri arasında kendilerinin öğrencilere okuma alışkanlığı kazandırma konusunda yeterli bilgi ve beceriye sahip olup olmadıklarına ilişkin düşünceleri açsından istatistiksel olarak anlamlı bir farklılık bulunmamıştır.

“Bölümünüz ders programında okuma alışkanlığı ile ilgili yeterli sayıda ve içerikte dersin olduğunu düşünüyor musunuz?" sorusu da öğrencilere sorulmuş ve elde edilen veriler Tablo 10'da sunulmuştur.

Tablo 10. Öğrencilerin Bölümün Ders Programında Okuma Alışkanlığı İle İlgili Yeterli Sayıda ve İçerikte Dersin Olduğuna Dair Düşünceleri

\begin{tabular}{lcccccc}
\hline & \multicolumn{2}{c}{ KMÜ } & & BDÜ & P \\
\hline $\begin{array}{l}\text { Okuma alışkanlığı ile ilgili yeterli sayıda/içerikte derslerin } \\
\text { olduğunu düşünüyor musunuz? }\end{array}$ & Sayı & $\%$ & \multicolumn{2}{c}{ Sayı } & $\%$ \\
\hline Evet & 36 & 40,5 & 51 & 52,1 & \\
Hayır & 31 & 34,8 & 16 & 16,3 & 0,01 \\
Kısmen & 22 & 24,7 & 31 & 31,6 \\
\hline Toplam & $\mathbf{8 9}$ & $\mathbf{1 0 0 , 0}$ & $\mathbf{9 8}$ & $\mathbf{1 0 0 , 0}$ \\
\hline
\end{tabular}

Tablo 10'daki bulgulara göre, TDE Bölümündeki öğrencilerin yarıdan azı $(\% 40,5)$, ADE Bölümündeki öğrencilerin ise yarıdan biraz fazlası $(\% 52,1)$ bölümün ders programlarında okuma alışkanlığı kazandırılmasına yönelik derslerin olduğunu düşünmektedirler. Bu oranlar, bölümlerde öğrencilerin yarıya yakın kısmının bu konuda yeterli eğitimi alamadıklarını düşündükleri anlamına gelmektedir. Yapılan Ki-kare analizine göre $(P=0,01)$ iki bölüm öğrencileri arasında okudukları bölüm programlarında okuma alışkanlığı ile ilgili yeterli sayı ve içerikte ders olup olmadığına ilişkin düşünceleri açsından BDÜ öğrencileri lehine istatistiksel olarak anlamlı bir farklılık bulunmuştur.

\section{Sonuç ve Öneriler}

KMÜ Türk Dili ve Edebiyatı Bölümü ile BDÜ Azerbaycan Dili ve Edebiyatı Bölümü son sınıf öğrencilerinin okuma alışkanlıklarının karşılaştırmalı olarak incelendiği bu çalışmanın temel amacı, BDÜ ADE Bölümü ile KMÜ TDE Bölümü son sınıf öğrencilerinin okuma alışkanlığı konusunda benzer ve farklı özelliklerini ortaya koymaktır. Hem karşılaştırmalı çalışma niteliği hem de okuma alışkanlığı olgusunda kültürün etkisini ortaya koyması açısından farklı coğrafyalarda yer alan ancak ortak bir kültüre (Türk kültürüne) sahip iki ülke üniversite öğrencilerinin okuma alışkanlıklarını belirlemek çalışmanın önemli ve özgün yanını oluşturmuştur. 
Bu bağlamda çalışmada elde edilen sonuçlar kısaca şöyle sıralanabilir:

1. Farklı ülkelerdeki üniversite öğrencileri arasında yapılmasına karşın, okuma alışkanlığı açısından öğrenciler arasında benzer özelliklerin farklılıklara göre daha fazla çıkması bu araştırmanın en özgün sonucu olarak değerlendirilebilir. Bunda araştırmaya dâhil edilen farklı ülkelerin ortak bir kültüre ve tarihe sahip olmasının etkili olduğu düşünülebilir. Okuma alışkanlığının kültürel nitelikte bir alışkanlık olması ve bu iki ülkenin benzer kültüre sahip olması bu benzerliklerde etkili olabilir. Ayrıca her iki bölümün anadil eğitimi veren ve fiilen büyük oranda öğretmen yetiştiren bölümler olması da benzerliklere neden olabilir.

2. Hem TDE $(\% 43,8)$ hem de ADE $(\% 71,4)$ Bölümü öğrencileri benzer biçimde en çok kendilerini geliştirmek amacıyla okumaktadırlar. TDE Bölümü öğrencilerinin bilgi birikimlerini artırma ve eğitime katkı sağlamak amacıyla okuma durumları ADE Bölümüne göre daha yüksektir.

3. Hem TDE $(\% 39,4)$ hem de $\operatorname{ADE}(\% 45,9)$ Bölümü öğrencilerinin büyük çoğunluğu benzer biçimde ayda ortalama bir kitap okumaktadır. Azerbaycan Dili ve Edebiyatı Bölümü öğrencileri gerek hiç okumama ve gerekse güçlü okuma sıklığı açılarından Türk Dili ve Edebiyatı Bölümü öğrencilerine göre daha iyi durumdadır.

4. Her iki bölüm öğrencileri de kitap okumaktan orta düzeyde (TDE \%51,8; ADE $\% 51,0)$ hoşlanmaktadırlar. Hem TDE hem de ADE Bölümü öğrencileri arasında kitap okumaktan az hoşlanan ve hiç hoşlanmayan öğrenciler az da olsa görülmektedir.

5. Hem TDE $(\% 42,7)$ hem de ADE $(\% 62,2)$ bölümü öğrencileri genellikle dergi ve gazete okumamaktadırlar. Her gün 3 ve daha fazla gazete, 1 ayda 3 ve daha fazla dergi okuyan öğretmen adaylarının oranı bu iki bölümde oldukça azdır. Gazete ve dergi okurluğu açısından her iki bölüm öğrencilerinin de okuma alışkanlıklarının oldukça düşük olduğu söylenebilir.

6. Hem TDE $(\% 80,9)$ hem de ADE $(\% 72,4)$ Bölümü öğrencileri benzer biçimde en çok derslerin yoğunluğu nedeniyle yeteri kadar kitap okuyamamaktadırlar. ADE $(\% 42,9)$ Bölümü öğrencilerinin kitap fiyatlarının pahalılığı nedeniyle fazla okuyamama durumu TDE $(\% 19,1)$ Bölümü öğrencilerine göre daha belirgindir. Buna karşın TDE Bölümü öğrencilerinin bilgisayar/internet kullanımı nedeni ile kitap okumama durumu ADE Bölümü öğrencilerine göre daha yüksektir.

7. Hem TDE $(\% 56,2)$ hem de $\operatorname{ADE}(\% 56,0)$ Bölümü öğrencilerinin okuma alışkanlığı durumları "orta” olarak değerlendirilebilir. Her iki bölüm öğrencileri arasında okuma alışkanlığına sahip olmayan öğrenci sayısı yok denecek kadar düşüktür.

8. Her iki bölüm öğrencileri de okuma alışkanlığı kazandırmanın bir öğretmen için kesinlikle önemli (TDE \%75,2; ADE \%67,4) olduğunu düşünmektedirler.

9. Hem TDE hem de ADE Bölümü öğrencilerinin okuma alışkanlığı kazandırma konusundaki bilgi ve beceriye kısmen (TDE \%69,7; ADE \%66,3) sahip olduklarını 
düşündükleri görülmektedir. Her iki bölüm öğrencilerinin de okuma alışkanlığı kazandırma konusundaki bilgi ve beceriye tamamen sahip olma (TDE \%25,8; ADE $\% 29,6)$ durumları düşüktür.

10. TDE Bölümü öğrencilerinin yarıdan azı ADE Bölümü öğrencilerinin ise yarıdan biraz fazlası ders programlarında okuma alışkanlığı kazandırma konusunda derslerin olduğunu düşünmektedirler.

11. Araştırmada yapılan Ki-kare analiz sonuçlarına göre, iki bölüm öğrencileri arasında kitap okuma nedenleri, dergi-gazete okuma sıklıkları, bazı okumama nedenleri (bilgisayar-internet kullanma ve kitap fiyatları) ve okudukları bölüm programlarında okuma alışkanlığı ile ilgili yeterli sayı ve içerikte ders olup olmadığına ilişkin düşünceleri (4 unsur) açsından istatistiksel olarak anlamlı farklılık bulunmuştur. Araştırmada irdelenen diğer unsurlar (6 unsur) açısından iki bölüm öğrencileri arasında istatistiksel açıdan anlamlı bir farklılık bulunmamıştır.

12. Yapılan Ki-kare analiz verilerine dayanarak araştırmanın genel sonucu şöylece özetlenebilir: KMÜ TDE ile BDÜ ADE Bölümü öğrencilerinin okuma alışkanlıklarına ilişkin olarak "kitap okuma sıklıkları", "kitap okumaktan hoşlanma durumları", "kitap okumasına engel olan unsurlar", "şu anki okuma alışkanlığı durumları", "öğretmenlerin okuma alışkanlığı kazandırma görevleri" ve "okuma alışkanlığı kazandırma konusundaki bilgi ve becerilerine yönelik düşünceleri" açılarından aralarındaki benzerliklerin daha fazla olduğu söylenebilir. Buna karşın, iki bölüm öğrencileri arasında "kitap okuma nedenleri", "dergi-gazete okuma sıklıkları", "okumama nedenleri olarak bilgisayar-internet kullanma ile kitap fiyatları" ve "okudukları bölüm programlarında okuma alışkanlığı ile ilgili yeterli sayı ve içerikte ders olup olmadığına ilişkin düşünceleri" açılarından farlılıklarının fazla olduğu anlaşılmıştır.

Araştırmada elde edilen sonuçlara dayanarak şu öneriler sunulabilir:

1. Her iki bölümün de ders programına okuma ve kütüphane kullanma alışkanlığı konularını içeren bir ders konulmalıdır.

2. Öğrencilerin düzenli kitap, dergi ve gazete okuyucusu olmaları teşvik edilmelidir.

3. Bölümlerde öğrenciler için bu konularda konferans, seminer vb. etkinlikler düzenlenmelidir.

4. Öğrencilere dersler çerçevesinde verilecek araştırma ödevleri mutlaka kütüphane kullanmayı gerektirmelidir.

5. Öğretmen adaylarına stajları süresince gerçekleştirmeleri gereken etkinlikler arasına okuma alışkanlığı konusu da dâhil edilmelidir.

6. Öğrencilere dersler çerçevesinde kitap okuma ve değerlendirme ödevleri verilmelidir. 
7. Bölümlerdeki öğretim elemanları da okuma ve kütüphane kullanma konusunda öğrencilere örnek/model olmaya çalışmalıdırlar.

8. Bölümler farklı kurumlar, kuruluşlar, bölümler, üniversiteler vb. tarafından okuma alışkanlığı ile ilgili olarak düzenlenen etkinlikleri öğrencilere duyurmalıdır.

9. Araştırma kapsamına alınan her iki bölüm öğrencileri de sağlıklı teknoloji kullanımı ile teknoloji-okuma/kütüphane kullanma alışkanlığı ilişkisi konusunda bilgilendirilmelidir.

Gerçekleştirilen bu çalışma daha fazla sayıda Türk cumhuriyeti öğrencileri (ülkesi) ile yapılarak genişletilmelidir.

\section{Kaynakça}

Akanda, A. K. M., Eamin, A., Hoq, K. M. G. ve Hasan, N. (2013). Reading habits of students in school science and arts: A case study of Rajshahi University. Chinese Librarianship: An International Electronical Journal, 35, 60-71.

Altunışık, R. (2008). Anketlerde veri kalitesinin iyileştirilmesi için ÖNTEST (Pilot Test) yöntemleri. Pazarlama ve Pazarlama Araştırmaları Dergisi, 2, 1-17. www.pazarlama.org.tr adresinden erişildi.

American Library Association (ALA). (1978). Book reading and library usage: A study of habits and perceptions. New Jersey: Gallup.

Arı, E. ve Demir, M. K. (2013) Illköğretim bölümü öğretmen adaylarının kitap okuma alışkanlıklarının değerlendirilmesi. Ana Dili Eğitimi Dergisi, 1(1), 116-128. www.anadiliegitimi.com adresinden erişildi.

Aslantürk, E. (2008). Sınıföğretmenlerinin ve sınıföğretmeni adaylarının okumailgive alışkanlıklarının karşılaştırılması (Yüksek lisans tezi). Adnan Menderes Üniversitesi, Aydın. www.adudspace. adu.edu.tr adresinden erişildi.

Azerbaycan Cumhuriyeti 324 Sayılı Eğitim Kanunu [324 Nömrəli Azərbaycan Respublikası Təhsil haqqında qanunu]. (1992, 7 Ekim). www.edu.gov.az adresinden erişildi.

Azerbaycan Cumhuriyeti Anayasası [Azərbaycan Respublikası Konstitusiyası]. (1995). www.eqanun.az adresinden erişildi.

Baloğlu, B. (2009). Sosyal bilimlerde araştırma yöntemi. İstanbul: Der Yayınları.

Batur, Z. ve Berk, H. G. H. (2010). Öğretmen adaylarının okuma alışkanlıkları üzerine bir araştırma: Uşak Eğitim Fakültesi örneği. Uşak Üniversitesi Sosyal Bilimler Dergisi, 3(1), 32-49. www. dergipark.org.tr adresinden erişildi.

Boz, D. (2009). Kitaba çağrı sınavında insan. Ankara: Öncü Basımevi.

Bozpolat, E. (2010). Öğretmen adaylarının okuma alışkanlığına ilişkin tutumlarının değerlendirilmesi: Cumhuriyet Üniversitesi Eğitim Fakültesi örneği. Zeıtschrıft Für Die Welt Der Türken [Journal Of World Of Turks] 2(1), 411-428. www.dieweltdertuerken.org adresinden erişildi. 
Coşkun, E. (2002). Okumanın hayatımızdaki yeri ve okuma sürecinin oluşumu. Türklük Bilimi Araştırmaları Dergisi, 11, 231-244. www.dergipark.org.tr adresinden erişildi.

Çakın, İ. (1989). Karşılaştırmalı kütüphanecilik: Yöntemi ve özellikleri. Türk Kütüphaneciliği Dergisi, 3(1), 3-18. http://www.tk.org.tr/index.php/TK/article/view/1246/1240 adresinden erişildi.

Çıngı, H. (1990). Örnekleme kuramı. Ankara: Hacettepe Üniversitesi.

Edizer, Z. Ç. (2015). Türkçe öğretmen adaylarının kitap okuma alışkanlığına ilişkin tutumları ile üst bilişsel okuma stratejilerini kullanım düzeyleri arasındaki ilişki. Kastamonu Eğitim Fakültesi Dergisi, 23(2), 645-658. www.dergipark.org.tr adresinden erişildi.

Erbaş, E. P. (2018). Karamanoğlu Mehmetbey Üniversitesi Türk Dili ve Edebiyatı Bölümü ile Bakü Devlet Üniversitesi Azerbaycan Dili ve Edebiyatı Bölümü öğrencilerinin okuma alışkanlıkları üzerine karşılaştırmalı bir inceleme (Yayımlanmamış bilim uzmanlığı tezi). Hacettepe Üniversitesi, Ankara. www.bby.hacettepe.edu.tr adresinden erişildi.

Erdem, C. (2012). Türk Dili ve Edebiyatı öğretmen adaylarının okuma stratejilerini kullanma düzeyleri. Uluslararası Türkçe Edebiyat Kültür Eğitim Dergisi, 1(4), 162-186. www.tekedergisi. com adresinden erişildi.

Eroğlu, Z. D. (2013). Öğretmen adaylarının okuma alışkanlıkları ile doğru yazma becerileri arasındaki ilişki. Turkish Studies - International Periodical For The Languages, Literature and History of Turkish or Turkic, 8(9), 1441-1453. http://turkishstudies.net/files/turkishstudies/176 1297175_085Ero\%C4\%9FluZehraD.-1441-1453.pdf adresinden erişildi.

Firsova, T. G. (2013). Акмеолог детского чтения: К вопросу о тюторстве в читательском развитии [Children's reading acmeologist: To the question of tutorship for readers' development] Известия Саратовского Университета, Технология Развития 1(2), 103-109. www.akmepsy. sgu.ru adresinden erişildi.

Gömleksiz, M. N. (2004). Geleceğin öğretmenlerinin kitap okumaya ilişkin görüşlerinin değerlendirilmesi: Fırat Üniversitesi Eğitim Fakültesi örneği. Yüzüncü Yıl Üniversitesi Eğitim Fakültesi Dergisi, 1(1), 1-21. https://www.academia.edu/516356/Gelece\%C4\%9Fin_\%C3\%9 6\%C4\%9Fretmenlerinin_Kitap_Okumaya_\%C4\%Boli\%C5\%9Fkin_G\%C3\%B6r\%C3\%BC\%C 5\%9Flerinin_De\%C4\%9Ferlendirilmesi_F\%C4\%B1 rat_\%C3\%9Cniversitesi_E\%C4\%9Fitim_ Fak\%C3\%BCltesi_\%C3\%96rne\%C4\%9Fi_adresinden erişildi.

Hüseynova, T. (2013). Türkiye'deki üniversitelerde okuyan Türk asıllı öğrencilerin okuma alışkanlıklarına yönelik anket çalışması üzerine bir değerlendirme. Türkiyat Mecmuası, 23, 237245. www.dergipark.org.tr adresinden erişildi.

Kaptan, S. (1995). Bilimsel araştırma ve istatistik teknikleri. Ankara: Gazi Üniversitesi.

Karadağ, R. (2014). Okuma ilgisi, tutumları ve alışkanlığı konusunda yapılmış çalışmaların lisansüstü tezlere dayalı analizi: YÖK ve Proquest veri tabanları örneklemi. Pamukkale Üniversitesi Eğitim Fakültesi Dergisi, (35), 1-17. www.dergipark.org.tr adresinden erişildi.

Karamanoğlu Mehmetbey Üniversitesi (KMÜ). (2018). Sınav sistemi. www.kmu.edu.tr adresinden erişildi.

Kolcu, G. (2016, 6 Ağustos). Sözleşmeli öğretmen şartları ve kontenjanları belli oldu. Hürriyet. 25 Ekim 2017 tarihinde http://www.hurriyet.com.tr/egitim/iste-sozlesmeli-ogretmensartlari-40182979 adresinden erişildi. 
Kuş, Z. ve Türkyılmaz, M. (2010). Sosyal Bilgiler ve Türkçe öğretmeni adaylarının durumları: İlgi, alışkanlık ve okuma stratejilerini kullanım düzeyleri. Türk Kütüphaneciliği, 24(1), 11-32. www. tk.org.tr adresinden erişildi.

Lupinogina, Y. A. ve Zaroçinçeva, I. V. (2015). Обучение чтению иноязычных текстов студентов неязычновых вузов [Learning read foreign language texts of students of non-linguistic universities] Вестник Воронежского Государственного Университета: Лингвистика и Межкультерная Комуникация 4, 142-145. www.vestnik.vsu.ru adresinden erişildi.

Maraşlı, A. (2005). Anne-babalar, eğitimciler ve gençler için: Okumayı sevdirme yolları. İstanbul: Bilge Yayınları.

Millî Eğitim Bakanlığı Öğretmen Atama ve Yer Değiştirme Yönetmeliği, T.C. Resmî Gazete (29329, 17 Nisan 2005).

Odabaş, H., Odabaş, Z. Y. ve Polat, C. (2008). Üniversite öğrencilerinin okuma alışkanlığı: Ankara Üniversitesi örneği. Bilgi Dünyası, 9(2), 431-465. www.bd.org.tr adresinden erişildi.

Özbay, M., Bağcı, H. ve Uyar, Y. (2008). Türkçe öğretmeni adaylarının okuma alışkanlığına yönelik tutumlarının çeşitli değişkenlere göre değerlendirilmesi. İnönü Üniversitesi Eğitim Fakültesi Dergisi, 9(15), 117-136. www.dergipark.com.tr adresinden erişildi.

Serin, N. (2011). Okuma alışkanlığının kazandırılmasında edebi türlerin etkisi (Yayımlanmamış yüksek lisans tezi). Atatürk Üniversitesi, Erzurum.

Yalman, M., Erdost, Ö. ve Kutluca, T. (2013). Eğitim Fakültesi öğrencilerinin kitap okuma alışkanlıkları üzerine betimsel bir araştırma: Dicle Üniversitesi örneği, Bilgi Dünyası 14 (2), 291-305. www. bd.org.tr adresinden erişildi.

Yıldız, D., Ceren, D. ve Sevmez, H. (2015). Eğitim Fakültesi öğrencilerinin okuma alışkanlıkları profili. Uşak Üniversitesi Sosyal Bilimler Dergisi, 8(3), 141-166. www.dergipark.org.tr adresinden erişildi.

Yılmaz, B. (1990). Okuma alışkanlığı ve Yenimahalle Illçe Halk Kütüphanesi. (Yüksek lisans tezi). Hacettepe Üniversitesi, Ankara. www.bby.hacettepe.edu.tr adresinden erişildi.

Yılmaz, B. (2002). Ankara'daki ilköğretim öğretmenlerinin okuma ve halk kütüphanesi kullanma alışkanlıkları üzerine bir araştırma. Türk Kütüphaneciliği, 16(4), 441-460. http://www.tk.org.tr/ index.php/TK/article/view/875 adresinden erişildi.

Yılmaz, B. (2004). Öğrencilerin okuma ve kütüphane kullanma alışkanlıklarında ebeveynlerin duyarlılığı. Bilgi Dünyası, 5 (2), 115-136. http://bd.org.tr/index.php/bd/article/view/229 adresinden erişildi.

Yılmaz, M. ve Benli, N. 2010). Sınıf öğretmeni adaylarının okuma alışkanlığına yönelik tutumlarının bazı değişkenlere göre incelenmesi. Erzincan Üniversitesi Eğitim Fakültesi Dergisi, 12(1), 281 291. https://dergipark.org.tr/tr/download/article-file/67623 adresinden erişildi.

Yükseköğretim kurumlarında lisans ve yüksek lisans derecesinde eğitim sisteminin düzenlenmesine ilişkin kuralların" onaylanması hakkında 348 Sayılı Kararname [348 Nömrəli Qərar. Ali təhsil müəssisələrinin bakalavriat və magistratura səviyyələrində, əsas (baza ali) tibb təhsilində və Azərbaycan Milli Elmlər Akademiyasının magistratura səviyyəsində kredit sistemi ilə tədrisin təşkili Qaydaları"nın təsdiq edilməsi haqqında qərar]. (2013, 24 Aralık). www.eqanun.az adresinden erişildi. 